\title{
The MIC and MBC of Silver Nanoparticles against Enterococcus faecalis - A Facultative Anaerobe
}

\author{
Ramesh Krishnan*, Vijay Arumugam and Suresh Kumar Vasaviah
}

Department of Pedodontics and Preventive Dentistry, Ariyanoor, Salem, Tamil Nadu, India

\begin{abstract}
Aim: To determine the Minimum Inhibitory Concentration (MIC) and Minimum Bactericidal Concentration (MBC) of silver nanoparticles against Enterococcus faecalis (E.faecalis)

Methodology: The antimicrobial efficacy of the silver nanoparticles was determined by the standard methods of Clinical and Laboratory Standards Institute (CLSI). Different concentrations of silver nanoparticles were prepared, and MIC was calculated by tube macro dilution method. The MBC was determined by the lowest concentration that kills $99.9 \%$ of the initial bacterial population. The data was analyzed by non-parametric test of Kruskal-Wallis using SPSS software package (version 17).
\end{abstract}

Results: The MIC and MBC of silver nanoparticles against $E$. faecalis was found to be optimum at $5 \mathrm{mg} / \mathrm{ml}$.

Conclusion: The result obtained from this study shows that silver nanoparticles have potential bactericidal effects against $E$. faecalis at a concentration of $5 \mathrm{mg} / \mathrm{ml}$. Silver nanoparticles can be incorporated in the root canal medicaments, sealers and irrigants, as it possess potent antimicrobial efficacy against $E$. faecalis.

Significance and impact of study: The antimicrobial property of silver nano particles against E.faecalis can be used clinically as an alternate to various other intra canal medicaments as irrigants.

Keywords: E. faecalis; Endodontic infections; Silver nanoparticles; MIC; MBC

\section{Introduction}

E. faecalis are one of the normal commensal of human and animal gastrointestinal tract. They are responsible for a variety of human infections including bacteraemia, infective endocarditis, urinary tract infections and endodontic infections $[1,2]$. It is most frequently isolated with greater numbers in post endodontic treatment cases due to the production of proteolytic enzymes, aggregation substances and adhesions [3]. They possess certain characteristics and virulence factors which enable them to survive for a longer period of time in the root canal. In addition, E. faecalis has the ability to survive long periods of starvation [4,5] form biofilms [6] invade and live within the dentinal tubules [7]. It can also acquire exogenous DNA, which may confer resistance to antimicrobials, such as tetracycline, recently sequenced genome of E. faecalis V583 is composed of over 25\% DNA, which is believed to be either mobile or from a foreign source [8].

Silver a precious metal, has been used for thousands of years by humans in different applications as jewellery, tools, coins, photographic material or explosives. Traditionally Hippocrates described the use of silver powder for wound healing and treatment of ulcers [9]. In medicine, silver plays a pivotal role as an antimicrobial agent. Nevertheless, after the introduction of antibiotics in 1940, the use of silver salts decreased and silver compounds were used in different biomedical fields, especially in treatment of burns [10]. Silver when compared to other metals, it's more toxic to microorganisms in the following descending sequence: $\mathrm{Ag}>\mathrm{Hg}>\mathrm{Cu}>\mathrm{Cd}>\mathrm{Cr}>\mathrm{Pb}>\mathrm{Co}$ $>\mathrm{Au}>\mathrm{Zn}>\mathrm{Fe}>\mathrm{Mn}>\mathrm{Mo}>\mathrm{Sn}$ with low toxicity to mammalian cells. Another advantage of silver is the low propensity to induce microbial resistance than many other antimicrobial materials [11].

Currently, nanoscale materials have emerged as novel antimicrobial agents owing to their high surface area to volume ratio and the unique chemical and physical properties [12]. Ag-NPs show efficient antimicrobial efficacy due to their large surface area hence providing better contact with microorganisms [13]. A few studies have exhibited excellent antibacterial activity of silver nanoparticles on microorganisms, which are considered as nontoxic and environment friendly antibacterial materials with broad-spectrum of activity and far lower propensity to induce microbial resistance than antibiotics. Previous studies have investigated the antibacterial effect of Ag-NPs on both gram positive and negative bacteria such as Staphylococcus aureus, Escherichia coli, Pseudomona aeruginosa and Staphylococcus epidermid $[14,15]$. Though the MIC of Ag-NPs on E. faecalis has been reported [16]. MBC of Ag-NPs on E. faecalis is yet to be established. The aim of the present study was to assess the antimicrobial efficacy of Ag-NPs against $E$. faecalis strain by determining both MIC and MBC.

\section{Materials and Methods}

\section{Silver nanoparticles formulation}

Silver nanoparticles of average particle size of 45-50 nm was obtained from Auto Fibre Craft (AFC, India). The bulk concentration of Ag-NPs in fluid form was prepared by dissolving $400 \mathrm{mg}$ of silver nanoparticles in $40 \mathrm{ml}$ of Brain Heart Infusion (BHI) broth and the mixture was prepared using an ultrasonic homogenizer.

*Corresponding author: Ramesh Krishnan, Professor, Department of Pedodontics and Preventive Dentistry, VMSDC, NH 47 Sankari Main Road, Ariyanoor, Salem 636 308, Tamil Nadu, India, Tel: 91-99605 83896; E-mail: drrameshk@gmail.com

Received March 24, 2015; Accepted April 09, 2015; Published April 19, 2015

Citation: Krishnan R, Arumugam V, Vasaviah SK (2015) The MIC and MBC of Silver Nanoparticles against Enterococcus faecalis - A Facultative Anaerobe. J Nanomed Nanotechnol 6: 285. doi:10.4172/2157-7439.1000285

Copyright: (c) 2015 Krishnan R, et al. This is an open-access article distributed under the terms of the Creative Commons Attribution License, which permits unrestricted use, distribution, and reproduction in any medium, provided the original author and source are credited. 


\section{E. faecalis strains, medium, and cultivation}

Ampoule of freeze dried E. faecalis reference strain (ATCC-35550) from the Institute of Microbiology Testing and Technology,(IMTECH, Chandigarh, India) was revived by adding 0.3 to 0.4 mlof the Brain Heart Infusion Broth (Hi-Media, Mumbai, India) under sterile condition as per the instructions of IMTECH. The revived bacteria BHI broth was centrifuged at $11000 \mathrm{rpm}$ for 5 minutes and the supernatant was discarded, $20 \mathrm{ml}$ of normal saline was added to the bacterial precipitate and further centrifuged. Again supernatant was discarded, and $20 \mathrm{ml}$ of sterile normal saline was added. The bacterial precipitate thus obtained was washed in normal saline and was viable and non-growing. This was maintained as an undiluted stock solution. Then the concentration was adjusted by spectrophotometer to an optical density of 0.10 at $625 \mathrm{~nm}$ $\left(1 \times 10^{8} \mathrm{CFU} / \mathrm{ml}, 0.5 \mathrm{McF}\right.$ arland's standard $)$

\section{MIC and $\mathrm{MBC}$ determination}

The antimicrobial efficacy of silver nano particles (Ag-NPs) was examined using the standard broth dilution method (CLSI M07-A8). The MIC was determined in BHI broth using serial two-fold dilutions of Ag-NPs in concentrations ranging from $0.132 \mathrm{mg} / \mathrm{ml}$ to $10 \mathrm{mg} / \mathrm{ml}$ with adjusted bacterial concentration $\left(0.10\right.$ at $625 \mathrm{~nm}\left(1 \times 10^{8} \mathrm{CFU} /\right.$ $\mathrm{ml}, 0.5 \mathrm{McF}$ arland's standard). The positive control used in this study contained BHI broth medium with tested bacterial concentrations and negative control contained only inoculated broth and the time and temperature of incubation being $24 \mathrm{~h}$ and $37^{\circ} \mathrm{C}$ respectively. The MIC is the lowest concentration of antimicrobial agents that visually inhibits $99 \%$ growth of microorganisms. The MIC was noted by the visual turbidity of the tubes both before and after incubation and it was done in six sets to confirm its value for the tested bacteria.

After the MIC determination of the Ag-NPs, aliquots of $50 \mu \mathrm{l}$ from all tubes which showed no visible bacterial growth were seeded in BHI agar plates, which are not supplemented with Ag-NPs, were incubated for $24 \mathrm{~h}$ at $37^{\circ} \mathrm{C}$. The $\mathrm{MBC}$ was observed for presence or absence of bacterial growth in agar plates both before and after incubation. The $\mathrm{MBC}$ endpoint is defined as the lowest concentration of antimicrobial agent that kills $99.9 \%$ of the initial bacterial population.

\section{Scoring}

For applying statistics, a numerical value was assigned to the observation such that the test tube sets which showed no inhibition of bacteria were given a numerical value 0 , and sets which showed inhibition of bacteria were given a numerical value 1. For MBC numerical value 0 given for bacterial growth and value 1 for no bacterial growth in agar plate

\section{Statistical analysis}

The data thus obtained were analyzed by using descriptive statistics including mean and standard deviation. Non-paired t-Test and Kruskal-Wallis Test were done for the analysis of MIC and MBC of Ag-NPs against E. faecalis Significance of all the statistical tests were predetermined at $P<0.01$ using SPSS (Statistical Package for Social Science) version 17 software.

\section{Results}

\section{Observations}

After 24 hours of incubation under aerobic condition at $37^{\circ} \mathrm{C}$, turbidity was noticed in all the test tubes ranging from 0.312 to 2.5 $\mathrm{mg} / \mathrm{ml}$ containing Ag-NPs indicating growth of bacteria. Whereas in

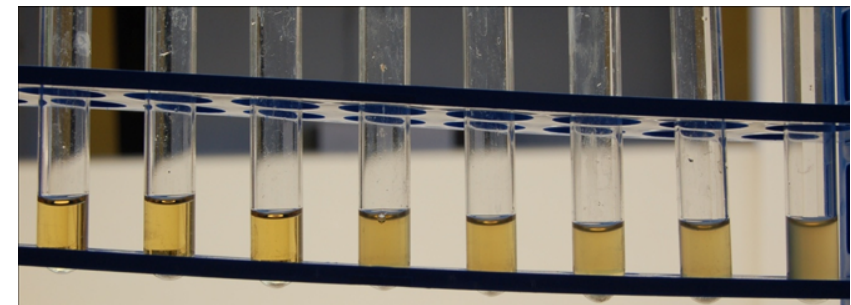

Figure 1: Test tubes showing absence of turbidity for 5 and10 $\mathrm{mg} / \mathrm{ml}$ (on the left).

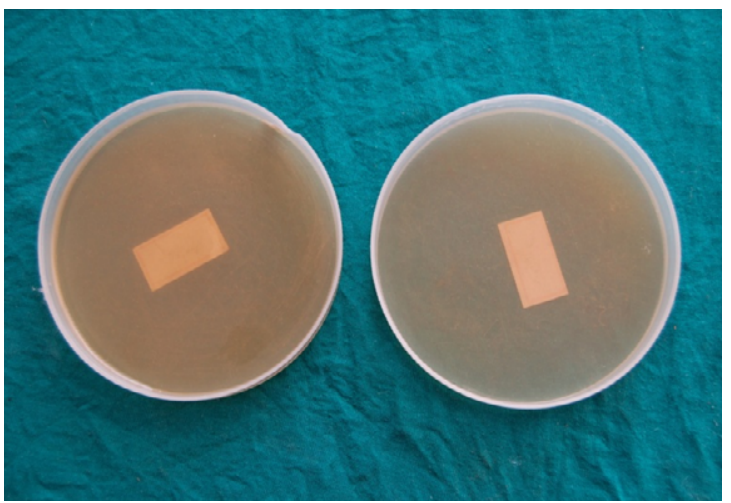

Figure 2: $\mathrm{BHI}$ agar plates showing inhibition of bacterial growth for 5 and $10 \mathrm{mg} / \mathrm{ml}$.

concentrations of 5 and $10 \mathrm{mg} / \mathrm{ml}$, no turbidity was seen exhibiting inhibition of bacterial growth (Figure 1). The suspension from the tubes of 5 and $10 \mathrm{mg} / \mathrm{ml}$ was inoculated in BHI agar plate and incubated for 24 hours and no growth of bacteria was observed in both the concentrations hence confirming it bactericidal (Figure 2). Presence or absence of turbidity was denoted as + or - respectively.

When bacterial growth at different concentrations of Ag- NPs was assessed after 24 hours, the MIC and MBC of E. faecalis was observed maximum for a concentration of $5 \mathrm{mg} / \mathrm{ml}$, and $10 \mathrm{mg} / \mathrm{ml}$, indicating it has both bacteriostatic and bactericidal activity (Tables 1 and 2). Statistical analysis of MBC for different concentrations when assessed showed significant inhibition of growth both for $5 \mathrm{mg} / \mathrm{ml}$ and $10 \mathrm{mg} /$ $\mathrm{ml}$ when compared to 0.312 to $2.5 \mathrm{mg} / \mathrm{ml}$, but the optimum MIC was obtained with $5 \mathrm{mg} / \mathrm{ml}$. These results thus confirms that the MIC and $\mathrm{MBC}$ of Ag-NPs was found to be effective at dilution of $5 \mathrm{mg} / \mathrm{ml}$.

\section{Discussion}

This study was aimed to evaluate the antibacterial effect of Ag-NPs on E. faecalis by MIC and MBC. Routine microbiological tests such as agar diffusion and MIC were commonly used to assess the antibacterial effect. In other studies, the agar diffusion test has been used routinely to evaluate the effectiveness of an antibacterial material against bacteria in a grown culture, and the diameter of the microbial inhibition zone depends on the solubility and infusibility of the test material as well therefore, it may not exhibit its full potential. Direct and close contact between the microorganism and the samples are evaluated by direct contact tests, independent of the diffusion properties of the tested material and media, which is an advantage over other tests similar to agar diffusion method [17]. MIC method uses serial dilutions of a solution to determine the lowest concentration of material that would still show antibacterial properties. 


\begin{tabular}{|c|c|c|c|c|c|c|}
\hline $\begin{array}{c}\text { Dilution of silver } \\
\text { nanoparticles for same no. of } \\
\text { bacteria in } \mathbf{m g} / \mathbf{m l}\end{array}$ & $\begin{array}{c}\mathbf{1 0} \\
\mathbf{m g} / \\
\mathbf{m l}\end{array}$ & $\begin{array}{c}\mathbf{5 ~ m g /} \\
\mathbf{m l}\end{array}$ & $\begin{array}{c}\mathbf{2 . 5} \\
\mathbf{m g} / \\
\mathbf{m l}\end{array}$ & $\begin{array}{c}\mathbf{1 . 2 5} \\
\mathbf{m g} / \mathbf{m l}\end{array}$ & $\begin{array}{c}\mathbf{0 . 6 2 5} \\
\mathbf{m g} / \\
\mathbf{m l}\end{array}$ & $\begin{array}{c}\mathbf{0 . 3 1 2} \\
\mathbf{m g} / \mathbf{m l}\end{array}$ \\
\hline Set 1 & - & - & + & + & + & + \\
\hline Set 2 & - & - & + & + & + & + \\
\hline Set 3 & - & - & + & + & + & + \\
\hline Set 4 & - & - & + & + & + & + \\
\hline Set 5 & - & - & + & + & + & + \\
\hline Set 6 & - & - & + & + & + & + \\
\hline
\end{tabular}

Positive $(+)=$ Turbidity indicating growth

Negative $(-)=$ No turbidity indicating absence of growth

Table 1: Bacterial growth in different concentrations of silver nanoparticles after 24 hours.

\begin{tabular}{|c|c|c|}
\hline $\begin{array}{c}\text { Dilution of silver } \\
\text { nanoparticles }\end{array}$ & $\mathbf{1 0} \mathbf{~ m g / m l}$ & $\mathbf{5 ~ m g / m l}$ \\
\hline Set 1 & - & - \\
\hline Set 2 & - & - \\
\hline Set 3 & - & - \\
\hline Set 4 & - & - \\
\hline Set 5 & - & - \\
\hline Set 6 & - & - \\
\hline
\end{tabular}

Positive $(+)=$ Indicating growth

Negative $(-)=$ Indicating absence of growth

Table 2: Minimum Bactericidal Concentrations of silver nanoparticles after 24 hours.

E. faecalis, a facultative anaerobic Gram-positive coccus, has been recovered from several oral sites [18]. It was selected for use in this study because it is among the few facultative bacteria associated with root canal failure cases and persistent apical periodontitis [19] and it exhibits a high level of resistance to a wide range of antimicrobial agents [20]. Also it has the ability to penetrate dentinal tubules thereby escaping from the action of endodontic instrumentation and irrigants [21].

The biologic effects of silver are believed to be closely related to silver ions [21,22]. In an aqueous microenvironment, Ag-NPs continuously release silver ions [23]. It is well known that smaller silver nano-particles show stronger and better bactericidal effect than larger particles because they have a larger surface area for interaction [24]. Binding to essential cellular structural elements like enzymes and other proteins [25], particularly to their SH-groups [26] and interfering with the integrity of the bacterial cell [27]. These are the main reasons for bactericidal properties of silver ions.

In this study, MIC and MBC of Ag-NPs against E. faecalis was determined by macrodilution method and was found to be effective at $5 \mathrm{mg} / \mathrm{ml}$. This is the first study in literature to include the MBC of AgNPs against $E$. faecalis. Lofti et al., demonstrated MIC of Ag-NPs even in concentrations of $50 \mu \mathrm{g} / \mathrm{ml}$ against $E$. faecais. This variation might be due to the methodology used to prepare Ag-NPs and size of the Ag-NPs used. They had prepared liquid form of Ag-NPs using a twostep procedure. First, nano-particles were produced using a catalytic chemical vapours deposition procedure and then added to distilled water. No surfactant was used in Ag-NPs fluid suspensions and average particle size was $35 \mathrm{~nm}$. The ultrafine particle size causes its action at lower concentration, whereas in our study commercially available AgNPs was used with the size of $50 \mathrm{~nm}$. Odabas et al. incorporated silver zeolite in mineral trioxide aggregate (MTA) and found the inhibitory effect was $0.2 \%$ and $2 \%$ concentration on E. faecalis [28].
A paramount consideration regarding the use of silver as an antimicrobial is its potentiality against development of microbial resistance to the greater extent. Silver resistance was found in both gram positive and gram negative bacteria, mediated by plasmid and transposon mechanisms. Humberto $\mathrm{H}$ Lara et al., in their study found that Ag-NPs are the effective broad-spectrum biocides against a variety of drug resistant bacteria [29]. Generally the nobel metal tends to induce low bacterial resistance [30], and has low toxicity and minimal side effects when ingested since at most $2-4 \%$ is retained in tissues after absorption by the body and a notable health effect is argyria, an irreversible pigmentation of the skin that is mostly an aesthetic concern [31].

Environmental Protection Agency (EPA) has established a chronic oral Reference Dose (RfD) of 5 micrograms $(\mu \mathrm{g})$ of silver per kilogram ( $\mathrm{kg}$ ) of body weight per day $(5 \mu \mathrm{g} / \mathrm{kg} /$ day). The Occupational Safety and Health Administration (OSHA) and the Mine Safety and Health Administration (MSHA) currently enforce a Permissible Exposure Limit (PEL) of $0.01 \mathrm{mg} / \mathrm{m}^{3}$ for metallic and soluble silver compounds [32]. MIC and MBC of Ag-NPs against E. faecalis was found to be 5 $\mathrm{mg} / \mathrm{ml}$ in this study. Thus the level falls well within the safety zone for in vivo applications.

It is necessary to recognize the limitations of in vitro antimicrobial testing per se and the difficulty in correlating in vitro results with the in vivo activity, as this the first study carried out in vitro, this will serve as an one of the most effective method in controlling dental infections from the root canals. Further studies are recommended, to address the efficacy of silver ions against endodontic pathogens, to elucidate the interactions of Ag-NPs in the dentinal structures, its cytotoxicity, mutagenicity and other potential long-term effects of Ag-NPs.

The results obtained from this study suggest that the effective bactericidal concentration of Ag-NPs against E. faecalis is $5 \mathrm{mg} / \mathrm{ml}$. The use of Ag-NPs as an antimicrobial agent against E. faecalis is possible. Incorporation of Ag-NPs into the intra canal medicaments, root canal sealers and also in irrigating solution can eradicate E. faecalis from the root canal and thereby success rate of root canal treatments can be increased. Further in vivo studies are needed to imply this effectively.

\section{References}

1. Mejàre $B$ (1975) Streptococcus faecalis and Streptococcus faecium in infected dental root canals at filling and their susceptibility to azidocillin and some comparable antibiotics. Odontol Revy 26: 193-204.

2. Pinheiro ET, Gomes BP, Drucker DB, Zaia AA, Ferraz CC, et al. (2004) Antimicrobial susceptibility of Enterococcus faecalis isolated from canals of root filled teeth with periapical lesions. Int Endod J 37: 756-763.

3. Molander A, Reit C, Dahlén G, Kvist T (1998) Microbiological status of root-filled teeth with apical periodontitis. Int Endod J 31: 1-7.

4. Stuart CH, Schwartz SA, Beeson TJ, Owatz CB (2006) Enterococcus faecalis its role in root canal treatment failure and current concepts in retreatment. J Endod 32: 93-98.

5. Figdor D, Davies JK, Sundqvist G (2003) Starvation survival, growth and recovery of Enterococcus faecalis in human serum. Oral Microbiol Immunol 18: $234-239$

6. Distel JW, Hatton JF, Gillespie MJ (2002) Biofilm formation in medicated root canals. J Endod 28: 689-693.

7. Akpata ES, Blechman $\mathrm{H}$ (1982) Bacterial invasion of pulpal dentin wall in vitro. J Dent Res 61: 435-438.

8. Paulsen IT, Banerjei L, Myers GS, Nelson KE, Seshadri R, et al. (2003) Role of mobile DNA in the evolution of vancomycin-resistant Enterococcus faecalis. Science 299: 2071-2074. 
Citation: Krishnan R, Arumugam V, Vasaviah SK (2015) The MIC and MBC of Silver Nanoparticles against Enterococcus faecalis - A Facultative Anaerobe. J Nanomed Nanotechnol 6: 285. doi:10.4172/2157-7439.1000285

9. Klasen $\mathrm{HJ}(2000)$ Historical review of the use of silver in the treatment of burns. I. Early uses. Burns 26: 117-130.

10. Zhao G, Stevens SE Jr (1998) Multiple parameters for the comprehensive evaluation of the susceptibility of Escherichia coli to the silver ion. Biometals 11: $27-32$.

11. Kim JS, Kuk E, Yu KN, Kim JH, Park SJ, et al. (2007) Antimicrobial effects of silver nanoparticles. Nanomedicine 3: 95-101.

12. Morones JR, Elechiguerra JL, Camacho A, Holt K, Kouri JB, et al. (2005) The bactericidal effect of silver nanoparticles. Nanotechnology 16: 2346-2353.

13. Rai M, Yadav A, Gade A (2009) Silver nanoparticles as a new generation of antimicrobials. Biotechnol Adv 27: 76-83.

14. Feng QL, Wu J, Chen GQ, Cui FZ, Kim TN, et al. (2000) A mechanistic study of the antibacterial effect of silver ions on Escherichia coli and Staphylococcus aureus. J Biomed Mater Res 52: 662-668.

15. Ha-Hymn Y, Hye-Kyoung J, Young-Jung J, Bong-Kyu C (2014) Enterococcus faecalis Activates Caspase-1 Leading to Increased Interleukin-1 Beta Secretion in Macrophages. Journal of Endodontics 40: 1587-1592.

16. Lotfi M, Vosoughhosseini S, Ranjkesh B, Khani S, Saghiri M, et al. (2011) Antimicrobial efficacy of nanosilver, sodium hypochlorite and chlorhexidine gluconate against Enterococcus faecalis Journal of Biotechnology 10: 67996803.

17. Estrela C, Rodrigues de Araújo Estrela C, Bammann LL, Pecora JD (2001) Two methods to evaluate the antimicrobial action of calcium hydroxide paste. J Endod 27: 720-723.

18. Rams TE, Feik D, Young V, Hammond BF, Slots J (1992) Enterococci in human periodontitis. Oral Microbiol Immunol 7: 249-252.

19. Haapasalo M, Ranta H, Ranta KT (1983) Facultative gram-negative enteric rods in persistent periapical infections. Acta Odontol Scand 41: 19-22.
20. Heath $\mathrm{CH}$, Blackmore TK, Gordon DL (1996) Emerging resistance in Enterococcus spp. Med J Aust 164: 116-120.

21. Chen X, Schluesener HJ (2008) Nanosilver: a nanoproduct in medical application. Toxicol Lett 176: 1-12.

22. Matsumura Y, Yoshikata K, Kunisaki S, Tsuchido T (2003) Mode of bactericidal action of silver zeolite and its comparison with that of silver nitrate. Appl Environ Microbiol 69: 4278-4281.

23. Lok CN, Ho CM, Chen R, He QY, Yu WY, et al. (2007) Silver nanoparticles: partial oxidation and antibacterial activities. J Biol Inorg Chem 12: 527-534.

24. Doty C, Tshikhudo R, Brust M, Fernig D (2005) Extremely stable water soluble Ag nanoparticles. Chem. Mater 17: 4630-4635

25. Ghandour W, Hubbard JA, Deistrung J, Hughes MN, Poole RK (1988) The uptake of silver ions by Escherichia coli: toxic effects and interactions with copper ions. Appl Microbiol Biotechnol 28: 559-565.

26. Petering HG (1976) Pharmacology and toxicology of heavy metals silver Pharmacol Ther A 1: 127-130

27. Schreurs WJ, Rosenberg H (1982) Effect of silver ions on transport and retention of phosphate by Escherichia coli. J Bacteriol 152: 7-13.

28. Odabaş ME, Cinar C, Akça G, Araz I, Ulusu T, et al. (2011) Short-term antimicrobial properties of mineral trioxide aggregate with incorporated silverzeolite. Dent Traumatol 27: 189-194.

29. Lara HH, Garza-Treviño EN, Ixtepan-Turrent L, Singh DK (2011) Silver nanoparticles are broad-spectrum bactericidal and virucidal compounds. J Nanobiotechnology 9: 30 .

30. Ip M, Lui SL, Poon VK, Lung I, Burd A (2006) Antimicrobial activities of silver dressings: an in vitro comparison. J Med Microbiol 55: 59-63.

31. Drake PL, Hazelwood KJ (2005) Exposure-related health effects of silver and silver compounds: a review. Ann Occup Hyg 49: 575-585

32. Http://www.cdc.gov/niosh/rtecs/vw3567e0 